\title{
Crystal Structure and Hirshfeld Surface Analysis of 1,2-Bis((2-
} (Bromomethyl)Phenyl)Thio)Ethane and Two Polymorphs of 1,2-Bis((2((Pyridin-2-ylthio)Methyl)Phenyl)Thio)Ethane

\section{Simplicio González-Montiel ${ }^{1 *}$, Saray Baca-Téllez ${ }^{1}$, Diego Martínez-Otero ${ }^{2}$, Alejandro Álvarez-Hernández ${ }^{1}$ and Julián Cruz-Borbolla ${ }^{1}$}

${ }^{1}$ Área Academic Chemistry, Chemical Research Center, University of the State of Hidalgo, $4.5 \mathrm{~km}$. Road Pachuca-Tulancingo, City of Knowledge, CP 42184, Mineral de la Reforma, Hidalgo, Mexico

${ }^{2}$ Joint Research Centre in Sustainable Chemistry, UNAM UAEM, Toluca-Atlacomulco Highway 14.5 km., C.P. 50200, Toluca, State of Mexico, Mexico

\begin{abstract}
1,2-Bis((2-(bromomethyl)phenyl)thio)ethane (1) and 1,2-bis((2-((pyridin-2-ylthio)methyl)phenyl)thio)ethane (2) were prepared and characterized by IR and NMR spectroscopy and single-crystal X-ray crystallography. X-ray diffraction studies shown that compound 1 crystallizes in a monoclinic space group $P 2 / n$ with crystal parameters $a=8.3970(3) \AA, b=12.4566(2) \AA, c=8.9251(3) \AA ; \beta=117.911(3)^{\circ}, V=824.96(5) \AA^{3}$ and $z=2$, and compound 2 exists in two monoclinic polymorphs $\left(\mathbf{2 a}\right.$ and $\mathbf{2 b}$ ). Polymorph $\mathbf{2 a}$ crystals are in space group $\mathrm{P} 2_{1}$, with unit cell parameters $a=5.3702(2) \AA, b=14.4235(6) \AA, c=15.4664(7) \AA, \beta=119.97(9)^{\circ}, V=1197.97(9) \AA^{3}$ and $z=2$, while polymorph $2 b$ crystals are in space group $P 2_{1} / c$ with unit cell parameters $a=7.8312(3) \AA, b=9.6670(4) \AA, c=16.2962(5) \AA, \beta=121.219(3)^{\circ}$; $V=1210.12(7) \AA^{3}$ and $z=2$. Variations in the crystal packing help to distinguish these two polymorphs via $\pi-\pi$ and $\mathrm{C}-\mathrm{H} \cdots \pi$ interactions. The 3D Hirshfeld surfaces and the associated 2D fingerprint plots have been performed to gain insight into the behavior of these interactions in compound $\mathbf{1}$ and polymorphs $\mathbf{2 a}$ and $\mathbf{2} \mathbf{b}$.
\end{abstract}

Keywords: Polymorphs; 1,2-bis((2-((pyridin-2-ylthio)methyl) phenyl)thio)ethane; Crystal packing; Hirshfeld surface; $\pi-\pi$ and $\mathrm{C}-\mathrm{H} \bullet \bullet \pi$ interactions

\section{Introduction}

Polymorphism is the ability of a particular molecule to exist in more than one crystal structure and it has great importance in pharmacology, solid-state chemistry, and material science since different polymorphs may have different physicochemical properties such as thermal behavior, stability, solubility, melting point, and bioavailability, among others [1-6]. Variations in structural units in a crystal leading to polymorphs occur through different intermolecular interactions such as $\mathrm{D}-\mathrm{H} \bullet$. A hydrogen bonding, $\pi-\pi$ stacking, $\mathrm{CH} \bullet \bullet \pi$, halogen $\bullet \bullet \pi$, halogen $\bullet \bullet$ halogen and anion $\bullet \bullet \pi$. These crystal structure modification in each polymorph result in different thermodynamic stability, i.e., the free energy of the crystals, kinetics of nucleation and crystal growth promoted by crystallization conditions (solvent, temperature, concentration, cocrystallization, pressure, etc.) [7-15]. These molecular Hirshfeld surfaces, so named because they derive from Hirshfeld's stockholder partitioning, divide the crystal into regions where the electron distribution of a sum of spherical atoms for the molecule (the promolecule) dominates the corresponding sum over the crystal (the procrystal). Hirshfeld surface analysis has gained prominence as a powerful tool to explore and describe a wide variety of intermolecular interactions within a crystal, [16-18] and it is almost always related to its corresponding 2D fingerprint-plot. This plot provides a convenient way to quantify intermolecular interactions within crystal structures and helps to reveal important information both about close contacts and also about more distant interactions and areas where contacts are weak [19-25].

Herewith we report the synthesis and structural study of two polymorphs of 1,2-bis((2-((pyridin-2-ylthio)methyl)phenyl)thio) ethane (2a and $\mathbf{2 b})$ and 1,2-bis((2-(bromomethyl)phenyl)thio)ethane (1) (Scheme 1) as part of our studies concerning the construction of novel metallomacrocycles based on ligands that contain in their structure two 2-mercaptopyridyl groups [26]. The intermolecular interactions that exist in the crystal structure of the two polymorphs have also been investigated by Hirshfeld surface analysis [23-25].

\section{Experiment}

\section{Materials and instrumentation}

All reagents are commercially available and were used without further purification. Melting points were measured in a Mel-Temp II instrument and are not corrected. Elemental analyses of the compounds were determined on a Perkin-Elmer Series II CHNS/O Analyzer. IR spectra were recorded on the $4000-400 \mathrm{~cm}^{-1}$ range on a Perkin-Elmer 2000 FTIR spectrometer as $\mathrm{KBr}$ pellets. ${ }^{1} \mathrm{H}$ NMR and ${ }^{13} \mathrm{C}\left\{{ }^{1} \mathrm{H}\right\}$ NMR spectra were recorded on a Varian Inova $400 \mathrm{NMR}$ spectrometer at $20^{\circ} \mathrm{C}$ in $\mathrm{CDCl}_{3}$ solutions; ${ }^{1} \mathrm{H}, 399.78 \mathrm{MHz}$ and residual protio-solvent signal were utilized as reference. Chemical shifts are quoted in the $\delta$ scale (downfield shifts positive) relative to tetramethylsilane $\left({ }^{1} \mathrm{H}\right)$. 1,2-bis-(2-hydroxymethylphenylthio)ethane $\quad\left(\mathrm{HOCH}_{2} \mathrm{Ph}-\mathrm{S}-\mathrm{CH}_{2}-\right.$ $\left.\mathrm{CH}_{2}-\mathrm{S}-\mathrm{PhCH}_{2} \mathrm{OH}\right)$ was prepared according to a previously reported protocol [27].

Synthesis of 1,2-bis((2-(bromomethyl)phenyl)thio)ethane (1) and 1,2-bis((2-((2-pyridinylthio)methyl)phenyl)thio)ethane (2)

Preparation of 1,2-bis((2-(bromomethyl)phenyl)thio)ethane (1): 1,2-bis-(2-hydroxymethylphenylthio)ethane $(8.15 \mathrm{mmol}, 2.5 \mathrm{~g})$

*Corresponding author: Simplicio González-Montiel, Área Académica de Química, Centro de Investigaciones Químicas, Universidad Autónoma del Estado de Hidalgo, km. 4.5 Carretera Pachuca-Tulancingo, Ciudad del Conocimiento, C.P. 42184, Mineral de la Reforma, Hidalgo, México, Tel: +52-771-71-72-000; Fax: +52771-71-72-000; E-mail: gmontiel@uaeh.edu.mx

Received May 07, 2015; Accepted June 12, 2015; Published June 17, 2015

Citation: González-Montiel S, Baca-Téllez S, Martínez-Otero D, ÁlvarezHernández A, Cruz-Borbolla J, et al. (2015) Crystal Structure and Hirshfeld Surface Analysis of 1,2-Bis((2-(Bromomethyl)Phenyl)Thio)Ethane and Two Polymorphs of 1,2-Bis((2-((Pyridin-2-ylthio)Methyl)Phenyl)Thio)Ethane. Mod Chem appl 3: 154. doi:10.4172/2329-6798.1000154

Copyright: () 2015 González-Montiel S et al. This is an open-access article distributed under the terms of the Creative Commons Attribution License, which permits unrestricted use, distribution, and reproduction in any medium, provided the original author and source are credited. 
Citation: González-Montiel S, Baca-Téllez S, Martínez-Otero D, Álvarez-Hernández A, Cruz-Borbolla J, et al. (2015) Crystal Structure and Hirshfeld Surface Analysis of 1,2-Bis((2-(Bromomethyl)Phenyl)Thio)Ethane and Two Polymorphs of 1,2-Bis((2-((Pyridin-2-ylthio)Methyl)Phenyl)Thio) Ethane. Mod Chem appl 3: 154. doi:10.4172/2329-6798.1000154

Page 2 of 7

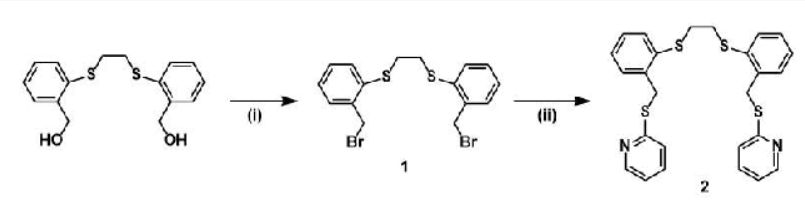

Scheme 1: Synthetic route established for preparation of 1 and 2. (i) $\mathrm{HBr}$ toluene, reflux, 5 days; (ii) 2-mercaptopyridine, $\mathrm{Cs}_{2} \mathrm{CO}_{3}$, toluene, reflux, $16 \mathrm{~h}$.

was dissolved in $50 \mathrm{~mL}$ of toluene and hydrobromic acid, $48 \%(25 \mathrm{~mL})$ was added; the mixture was refluxed for 5 days. After cooling to room temperature, the two layers were separated and the organic layer was dried with $\mathrm{NaSO}_{4}$, then filtered through a bed of Celite and the solvent was removed under reduced pressure to give a white solid. Yield: $3.15 \mathrm{~g}$ (90\%). m.p. $=111-115^{\circ} \mathrm{C}$. Anal. Calc. for $\mathrm{C}_{16} \mathrm{H}_{16} \mathrm{Br}_{2} \mathrm{~S}_{2}: \mathrm{C}, 44.46 ; \mathrm{H}, 3.73$. Found: C, 44.16; $\mathrm{H}, 3.83 \% .{ }^{1} \mathrm{H}$ NMR $\left(399.78 \mathrm{MHz}, \mathrm{CDCl}_{3}\right): \delta=7.45-$ $7.42(2 \mathrm{H}, \mathrm{m}, \mathrm{H} 1), 7.37-7.34(2 \mathrm{H}, \mathrm{m}, \mathrm{H} 4), 7.30-7.24(4 \mathrm{H}, \mathrm{m}, \mathrm{H} 2$ and $\mathrm{H} 3), 4.70\left(4 \mathrm{H}, \mathrm{s}, \mathrm{CH}_{2}-\mathrm{Br}\right), 3.18\left(4 \mathrm{H}, \mathrm{s}, \mathrm{S}-\mathrm{CH}_{2}\right) \mathrm{ppm} .{ }^{13} \mathrm{C}\left\{{ }^{1} \mathrm{H}\right\} \mathrm{NMR}$ $\left(100.53 \mathrm{MHz}, \mathrm{CDCl}_{3}\right): \delta 138.68$ (C6), 135.05 (C5), 131.26 (C4), 130.99 (C1), 129.43 (C2), 127.49 (C3), $33.81\left(\mathrm{~S}_{-} \mathrm{CH}_{2}\right), 32.12\left(\mathrm{CH}_{2}-\mathrm{Br}\right) \mathrm{ppm}$. IR (KBr): 3058, 2966, 2920, 2852, 1588, 1567, 1466, 1443, 1431, 1218, $1203,1194,1063,1038,818,754,727,704,672,602,567,497,445 \mathrm{~cm}^{-1}$.

Preparation of 1,2-bis((2-((2-pyridinylthio)methyl)phenyl)thio) ethane (2): 1,2-bis((2-(bromomethyl)phenyl)thio)ethane (4.63 mmol, $2.0 \mathrm{~g})$ and 2-mercaptopyridine $(9.26 \mathrm{mmol}, 1.03 \mathrm{~g})$ were dissolved in 50 $\mathrm{mL}$ toluene, and then $\mathrm{Cs}_{2} \mathrm{CO}_{3}(4.63 \mathrm{mmol}, 1.51 \mathrm{~g})$ was added directly into the solution; the mixture was then refluxed for $16 \mathrm{~h}$. After cooling, the resulting suspension was filtered through Celite and the solvent was removed under reduced pressure to give a white solid. Yield 2.10 g (92\%). m.p. $=82-87^{\circ} \mathrm{C}$. Anal. Calc. for $\mathrm{C}_{26} \mathrm{H}_{24} \mathrm{~N}_{2} \mathrm{~S}$ : C, 63.38; H, 4.91; Found: C, $62.98 ; \mathrm{H}, 4.83 \% .{ }^{1} \mathrm{H}$ NMR $\left(399.78 \mathrm{MHz}, \mathrm{CDCl}_{3}\right): \delta=8.46(2 \mathrm{H}$, ddd, $\left.{ }^{3} J=4.96 \mathrm{~Hz},{ }^{4} J=1.84 \mathrm{~Hz},{ }^{5} J=0.94 \mathrm{~Hz}, \mathrm{H} 12\right), 7.49\left(2 \mathrm{H}, \mathrm{dd},{ }^{3} J=6.18\right.$ $\left.\mathrm{Hz},{ }^{4} J=2.96 \mathrm{~Hz}, \mathrm{H1}\right), 7.45\left(2 \mathrm{H}, \mathrm{ddd}, 3 J=8.05 \mathrm{~Hz},{ }^{4} J=7.41 \mathrm{~Hz},{ }^{5} J=1.88 \mathrm{~Hz}\right.$, H10), $7.31\left(2 \mathrm{H}, \mathrm{dd},{ }^{3} \mathrm{~J}=6.48 \mathrm{~Hz},{ }^{4} \mathrm{~J}=2.66 \mathrm{~Hz}, \mathrm{H} 4\right), 7.16(4 \mathrm{H}, \mathrm{m}, \mathrm{H} 2, \mathrm{H} 3)$, $7.13\left(2 \mathrm{H}, \mathrm{dd},{ }^{3} \mathrm{~J}=7.14 \mathrm{~Hz},{ }^{4} \mathrm{~J}=0.98 \mathrm{~Hz}, \mathrm{H} 9\right), 6.98\left(2 \mathrm{H}, \mathrm{ddd},{ }^{3} J=7.34 \mathrm{~Hz}\right.$, $\left.{ }^{4} \mathrm{~J}=4.95 \mathrm{~Hz},{ }^{5} \mathrm{~J}=1.02 \mathrm{~Hz}, \mathrm{H} 11\right), 4.62(4 \mathrm{H}, \mathrm{s}, \mathrm{H} 7), 3.14$ (2H, s, H8) ppm. 13C NMR (CDCl3): $\delta=158.80$ (C8), 149.42 (C12), 139.01 (C5), 136.11 (C10), 134.79 (C6), 130.82 (C1), 130.61 (C4), 128.10 (C2), 127.07 (C3), 122.36 (C9), 119.69 (11), 33.99 (C13), 32.91 (C7) ppm. IR (KBr): 3056, 2992, 2924, 2847, 1578, 1556, 1453, 1414, 1281, 1242, 1147, 1122, 1062, $1043,985,956,820,757,619,580,479 \mathrm{~cm}^{-1}$.

\section{$\mathrm{X}$-ray diffraction}

Suitable crystals of $\mathbf{1}$ were grown in toluene by slow evaporation while crystals of $\mathbf{2}$ were grown in dimethylsulfoxide and were separated by fractional crystallization; the polymorph $\mathbf{2 a}$ crystallized first after 2 weeks stored at room temperature and then crystals of polymorph $\mathbf{2 b}$ were obtained after 4 weeks at the same solution. All crystal structures were determined by X-ray analysis, and their crystallographic details and structure refinements are presented in Table 1. X-ray diffraction data were collected at room temperature on an Oxford Diffraction Gemini CCD diffractometer, using graphite-monochromated $\mathrm{Cu} \mathrm{Ka}$ radiation $(\lambda=1.54184 \AA)$ for $\mathbf{1}$ and Mo Ka radiation $(\lambda=0.71073 \AA)$ for $\mathbf{2 a}$ and $\mathbf{2 b}$. Data were processed using the Crysalis software package [28]. Using Olex2 [29], the structures were solved with the XS program [30] employing direct methods and refined with the XL refinement package using Least Squares minimization [30]. All non-hydrogen atoms were refined anisotropically and hydrogen atoms were located at calculated positions and refined using a riding model with isotropic thermal parameters fixed at 1.2 times the Ueq value of the appropriate carrier atom (Table 1$)$.

\section{Computational details}

The Hirshfeld surfaces and fingerprint plots were calculated using the Crystal Explorer (version 3.1) software [31].

\section{Results and Discussion}

\section{Synthesis of compounds 1 and 2}

Compound 1,2-bis((2-((2-pyridinylthio)methyl)phenyl)thio)etane (2) was prepared in good yield using an established route (Scheme 1). Thus, starting from 1,2-bis-(2-hydroxymethylphenylthio)etane [26] bromination using an excess of hydrobromic acid led to 1,2-bis((2(bromomethyl)phenyl)thio)etane (1). 1,2-bis((2-((2-pyridinylthio) methyl)phenyl)thio)etane was obtained from the reaction between 1,2-bis((2-(bromomethyl)phenyl)thio)ethane and 2-mercaptopyridine in presence of $\mathrm{Cs}_{2} \mathrm{CO}_{3}$. Compounds $\mathbf{1}$ and $\mathbf{2}$ are soluble in chloroform, dichloromethane, toluene, benzene and acetonitrile, and are insoluble in methanol, ethanol, pentane and $n$-hexanes.

\section{NMR spectroscopy}

The ${ }^{1} \mathrm{H}$ NMR spectrum of compound 1 show three signals at high frequencies corresponding to ortho-substituted benzene rings, two single signals at low frequencies correspond to the bridge ethylene group and the bromomethylene group. The ${ }^{1} \mathrm{H}$ NMR spectrum of compound 2 shows eight signals at high frequencies due to two $\mathrm{ABCD}$ patterns corresponding to the ortho-substituted benzene rings and to the ortho-substituted pyridine rings; signals at low frequencies correspond to the methylene groups that link the phenyl and pyridine rings and to the ethylene brigde between both phenyl rings.

The ${ }^{13} \mathrm{C}$ NMR spectrum of compound $\mathbf{1}$ shows six signals at high frequencies that are attributed to ortho-substituted benzene rings and two single signals at low frequencies corresponding to the methylene group link bromide and the ethylene group that brigde both phenyl rings. The ${ }^{13} \mathrm{C}-\mathrm{NMR}$ of compound 2 shows eleven signals at high frequencies which six are attributed to ortho-substituted benzene and pyridine rings, and two signals at low frequencies corresponding to methylene and ethylene groups. In solution, the two $-\mathrm{CH}_{2}-\mathrm{S}_{-}-\mathrm{C}_{6} \mathrm{H}_{4} \mathrm{~S}$ $\mathrm{CH}_{2}-\mathrm{Br}$ and $-\mathrm{CH}_{2}-\mathrm{S}-\mathrm{C}_{6} \mathrm{H}_{4} \mathrm{~S}-\mathrm{CH}_{2}-\mathrm{C}_{5} \mathrm{H}_{4} \mathrm{~N}$ units are equivalent.

\section{Molecular and crystal structures}

Molecular structures: The molecular structure of $\mathbf{1}, \mathbf{2} \mathbf{a}$ and $\mathbf{2 b}$ was confirmed by X-ray diffraction studies and their structure are depicted in Figures 1 and 2, and selected bond lengths, angles and torsion angles are given in Table 2 .

In all compounds $\mathbf{1}, \mathbf{2} \mathbf{a}$ and $\mathbf{2} \mathbf{b}$ the aromatic rings on the ethylene group adopt anti-conformation, i.e. the $-\mathrm{PhCH}_{2} \mathrm{Br}$ fragments in $\mathbf{1}$ and $-\mathrm{Ph}-\mathrm{CH}_{2}-\mathrm{S}-\mathrm{C}_{5} \mathrm{H}_{4} \mathrm{~N}$ fragments in $\mathbf{2} \mathbf{a}$ and $\mathbf{2} \mathbf{b}$ are positioned on opposite sides of the ethylene bridge with $\mathrm{C} 1-\mathrm{C} 7---\mathrm{C} 7^{\mathrm{i}}-\mathrm{C} 1^{\mathrm{i}}$ torsion angles in $\mathbf{1}$ and $2 \mathbf{b}$ equal to $180^{\circ}$ and $\mathrm{C} 1-\mathrm{C} 7--\mathrm{C} 8-\mathrm{C} 9$ torsion angle in $2 \mathbf{a}$ equal to $177.16^{\circ}$. In compounds $\mathbf{1}$ and $\mathbf{2 b}$ the phenyl rings $\left[\mathrm{Cg}_{\mathrm{A}}=\mathrm{C} 1 / \mathrm{C} 2 / \mathrm{C} 3 / \mathrm{C} 4 /\right.$ C5/C6 and $\mathrm{Cg}_{A^{\prime}}=\mathrm{C}^{\prime} / \mathrm{C}^{\prime} / \mathrm{C}^{\prime} / \mathrm{C}^{\prime} / \mathrm{C}^{\prime} / \mathrm{C}^{\prime}$ ', symmetry code: (i) $2-\mathrm{x}, 1-\mathrm{y}$, $1-z$ for $\mathbf{1}$ and $-x, 1-y,-z$ for $\mathbf{2 b}]$ are in an antiparallel manner in relation to each another with centroid-to-centroid distance $C g_{A} \bullet \bullet C g_{A^{\prime}}$ of 8.367 $\AA$ and $8.149 \AA$ for $\mathbf{1}$ and $\mathbf{2} \mathbf{b}$, respectively. While in $\mathbf{2} \mathbf{a}$ the phenyl rings $\left(C g_{A}=\mathrm{C} 1 / \mathrm{C} 2 / \mathrm{C} 3 / \mathrm{C} 4 / \mathrm{C} 5 / \mathrm{C} 6\right.$ and $\left.C g_{B}=\mathrm{C} 9 / \mathrm{C} 10 / \mathrm{C} 11 / \mathrm{C} 12 / \mathrm{C} 13 / \mathrm{C} 14\right)$ are nearly coplanar with the dihedral angle between the two phenyl rings being $9.76^{\circ}$ with centroid-to-centroid distance $C g_{A} \cdot \bullet C g_{B}$ of 9.407 
Citation: González-Montiel S, Baca-Téllez S, Martínez-Otero D, Álvarez-Hernández A, Cruz-Borbolla J, et al. (2015) Crystal Structure and Hirshfeld Surface Analysis of 1,2-Bis((2-(Bromomethyl)Phenyl)Thio)Ethane and Two Polymorphs of 1,2-Bis((2-((Pyridin-2-ylthio)Methyl)Phenyl)Thio) Ethane. Mod Chem appl 3: 154. doi:10.4172/2329-6798.1000154

Page 3 of 7

\begin{tabular}{|c|c|c|c|}
\hline Compound & 1 & $2 a$ & $2 b$ \\
\hline Empirical formula & $\mathrm{C}_{16} \mathrm{H}_{16} \mathrm{~S}_{2} \mathrm{Br}_{2}$ & $\mathrm{C}_{26} \mathrm{H}_{24} \mathrm{~N}_{2} \mathrm{~S}_{4}$ & $\mathrm{C}_{26} \mathrm{H}_{24} \mathrm{~N}_{2} \mathrm{~S}_{4}$ \\
\hline Formula weight & 432.23 & 492.71 & 492.71 \\
\hline Temperature [K] & $301.3(8)$ & $293(2)$ & $293(2)$ \\
\hline Crystal system & monoclinic & monoclinic & monoclinic \\
\hline Space group & $\mathrm{P} 2 / \mathrm{n}$ & $\mathrm{P} 2{ }_{1}$ & $\mathrm{P} 2_{1} / \mathrm{c}$ \\
\hline $\mathrm{a}[\AA]$ & $8.3970(3)$ & $5.3702(2)$ & $7.8312(3)$ \\
\hline $\mathrm{b}[\AA]$ & $12.4566(2)$ & $14.4235(6)$ & $9.6670(4)$ \\
\hline$c[\AA]$ & $8.9251(3)$ & $15.4664(7)$ & $16.2962(5)$ \\
\hline$\alpha\left[^{\circ}\right]$ & 90 & 90 & 90 \\
\hline$\beta\left[^{\circ}\right]$ & 117.911(3) & $90.215(4)$ & $101.219(3)$ \\
\hline $\mathrm{Y}\left[{ }^{\circ}\right]$ & 90 & 90 & 90 \\
\hline Volume $\left[\AA^{3}\right]$ & $824.96(5)$ & 1197.97(9) & $1210.12(7)$ \\
\hline Z & 2 & 2 & 2 \\
\hline$\rho_{\text {calcd }}\left[\mathrm{mg} / \mathrm{mm}^{-3}\right]$ & 1.740 & 1.366 & 1.352 \\
\hline$\mu\left[\mathrm{mm}^{-1}\right]$ & 8.483 & 0.414 & 0.410 \\
\hline$F(000)$ & 428.0 & 516.0 & 516.0 \\
\hline Crystal size $\left[\mathrm{mm}^{3}\right]$ & $0.48 \times 0.33 \times 0.33$ & $0.24 \times 0.09 \times 0.05$ & $0.27 \times 0.21 \times 0.19$ \\
\hline $\begin{array}{c}\text { Radiation } \\
\text { wavelength }[\AA]\end{array}$ & $\begin{array}{c}\text { CuKa } \\
(\lambda=1.54184)\end{array}$ & $\begin{array}{c}\text { MoKa } \\
(\lambda=0.71073)\end{array}$ & $\begin{array}{c}\text { MoKa } \\
(\lambda=0.71073)\end{array}$ \\
\hline $2 \Theta$ range for data collection $\left[{ }^{\circ}\right]$ & 11.952 to 134.152 & 5.978 to 52.78 & 6.604 to 52.742 \\
\hline Abs. correction & Analytical & Analytical & Analytical \\
\hline Index ranges & $\begin{array}{c}-10 \leq h \leq 9 \\
-14 \leq k \leq 14 \\
-10 \leq 1 \leq 10\end{array}$ & $\begin{aligned}-6 & \leq h \leq 6 \\
-18 & \leq k \leq 18 \\
-19 & \leq \mathrm{I} \leq 19\end{aligned}$ & $\begin{array}{c}-9 \leq \mathrm{h} \leq 9 \\
-12 \leq \mathrm{k} \leq 12 \\
-20 \leq \mathrm{I} \leq 20\end{array}$ \\
\hline Reflections collected & 3971 & 10460 & 17858 \\
\hline Unique reflections, $R_{\text {int }}$ & $1374,0.0384$ & $4690,0.0302$ & $2467,0.0261$ \\
\hline Data/restraints/parameters & $1374 / 0 / 92$ & $4690 / 238 / 289$ & $2467 / 0 / 145$ \\
\hline Goodness-of-fit (GOF) on $\mathrm{F}^{2}$ & 1.068 & 1.015 & 1.048 \\
\hline $\mathrm{R}_{1}, \mathrm{wR}_{2}[\mathrm{I}>=2 \sigma(\mathrm{I})]$ & $0.0416,0.1108$ & $0.0376,0.0649$ & $0.0327,0.0773$ \\
\hline $\mathrm{R}_{1}, \mathrm{wR}_{2}$ [all data] & $0.0441,0.1135$ & $0.0554,0.0707$ & $0.0414,0.0819$ \\
\hline Largest diff. peak/hole $\left[e \cdot \AA^{-3}\right]$ & $0.56 /-0.60$ & $0.22 /-0.18$ & $0.19 /-0.25$ \\
\hline
\end{tabular}

Table 1: Details of crystal data and structure refinement parameters for 1 and $2 \mathrm{a}$ and $2 \mathrm{~b}$.

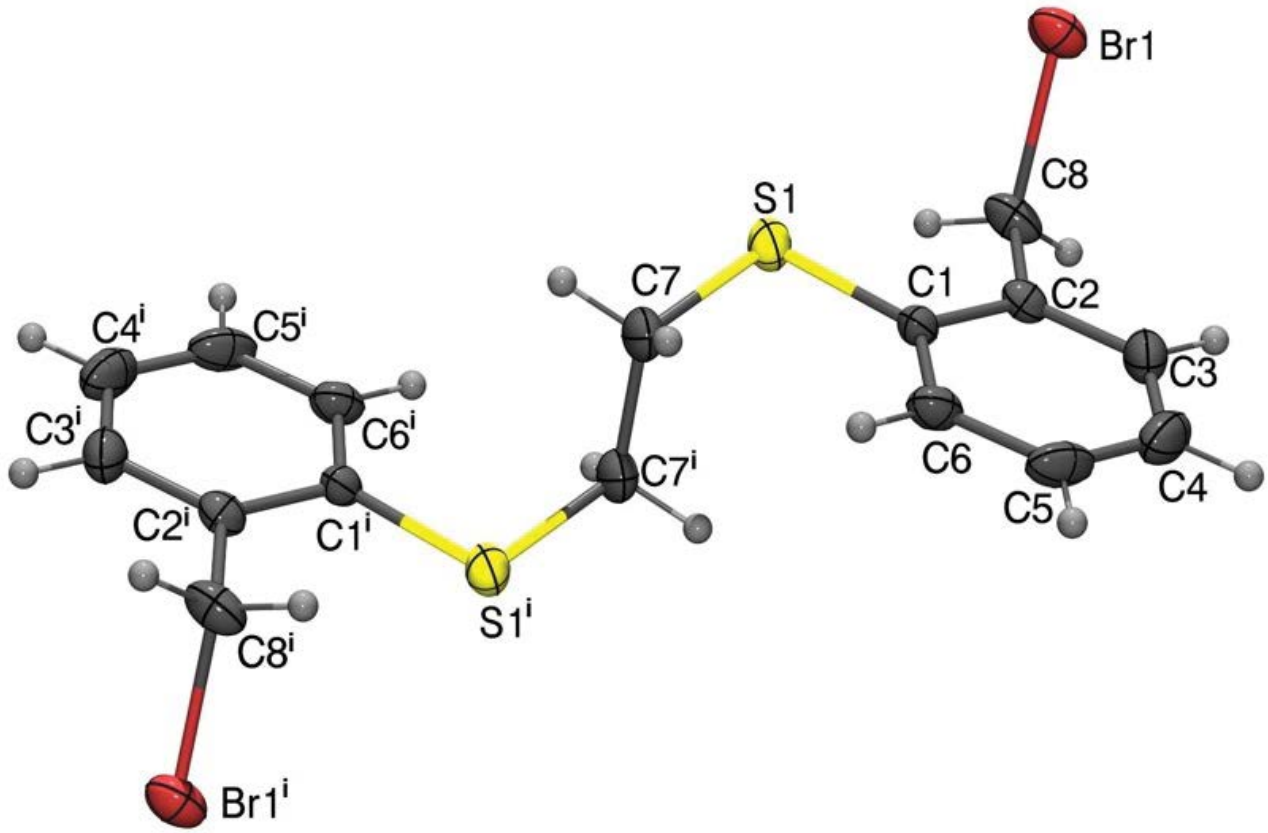

Figure 1: Molecular structure of compound 1, showing the atom labeling. Displacement ellipsoids are drawn at the $30 \%$ probability level. Symmetry code (i) $2-x$, $1-y, 1-z$. 
Citation: González-Montiel S, Baca-Téllez S, Martínez-Otero D, Álvarez-Hernández A, Cruz-Borbolla J, et al. (2015) Crystal Structure and Hirshfeld Surface Analysis of 1,2-Bis((2-(Bromomethyl)Phenyl)Thio)Ethane and Two Polymorphs of 1,2-Bis((2-((Pyridin-2-ylthio)Methyl)Phenyl)Thio) Ethane. Mod Chem appl 3: 154. doi:10.4172/2329-6798.1000154

Page 4 of 7

\begin{tabular}{|c|c|c|c|}
\hline Compound & 1 & $2 a$ & $2 b$ \\
\hline \multicolumn{4}{|l|}{ Bond length } \\
\hline $\mathrm{S} 1-\mathrm{C} 1$ & $1.772(3)$ & $1.770(3)$ & $1.7870(16)$ \\
\hline $\mathrm{S} 1-\mathrm{C} 7$ & $1.806(4)$ & $1.805(4)$ & $1.8165(17)$ \\
\hline $\mathrm{C} 7-\mathrm{C} 7^{\mathrm{i}}$ & $1.512(8)$ & & $1.505(3)$ \\
\hline $\mathrm{C} 7-\mathrm{C} 8$ & & $1.510(4)$ & \\
\hline $\mathrm{C} 8-\mathrm{Br} 1$ & $1.963(4)$ & & \\
\hline $\mathrm{S} 2-\mathrm{C} 8$ & & $1.808(4)$ & $1.8130(18)$ \\
\hline S2-C9 & & $1.768(3)$ & $1.7704(17)$ \\
\hline S3-C15 & & $1.823(3)$ & \\
\hline S3-C16 & & $1.760(4)$ & \\
\hline S4-C21 & & $1.818(3)$ & \\
\hline S4-C22 & & $1.766(4)$ & \\
\hline N1-C9 & & & $1.324(2$ \\
\hline $\mathrm{N} 1-\mathrm{C} 13$ & & & $1.347(2)$ \\
\hline N1-C16 & & $1.318(5)$ & \\
\hline N1-C20 & & $1.345(6)$ & \\
\hline N2-C22 & & $1.321(4)$ & \\
\hline N2-C26 & & $1.344(5)$ & \\
\hline \multicolumn{4}{|l|}{ Bond angle } \\
\hline C1-S1-C7 & 104.92(19) & $102.72(16)$ & 101.32(7) \\
\hline $\mathrm{C} 2-\mathrm{C} 1-\mathrm{S} 1$ & $117.6(3)$ & $117.9(3)$ & $120.30(12)$ \\
\hline C6-C1-S1 & 123.3(3) & $122.8(3)$ & $119.74(13)$ \\
\hline C7'-C7-S1 & $113.8(4)$ & & $112.82(15)$ \\
\hline $\mathrm{C} 2-\mathrm{C} 8-\mathrm{Br} 1$ & $110.0(3)$ & & \\
\hline C8-C7-S1 & & 108.3(2) & \\
\hline C9-S2-C8 & & $103.14(16)$ & 103.62(8) \\
\hline C22-S4-C21 & & $101.76(18)$ & \\
\hline S2-C9-N1 & & & $120.96(13)$ \\
\hline N1-C16-S3 & & $120.6(3)$ & \\
\hline N2-C22-S4 & & 118.9(3) & \\
\hline \multicolumn{4}{|l|}{ Torsion angle } \\
\hline S1-C1-C2-C3 & $176.2(3)$ & $176.6(3)$ & $-176.02(12)$ \\
\hline S1-C1-C2-C8 & $-2.7(5)$ & & $4.3(2)$ \\
\hline $\mathrm{C} 3-\mathrm{C} 2-\mathrm{C} 8-\mathrm{Br} 1$ & $-86.6(4)$ & & \\
\hline $\mathrm{C} 1-\mathrm{C} 2-\mathrm{C} 8-\mathrm{Br} 1$ & $92.4(4)$ & & \\
\hline C3-C2-C8-S2 & & & $113.55(16)$ \\
\hline C7-S1-C1-C2 & 164.3(3) & 178.1(2) & \\
\hline C1-S1-C7-C7i & $-71.7(5)$ & & $71.55(18)$ \\
\hline C7-S1-C1-C6 & $-19.0(4)$ & $-0.7(3)$ & $62.25(15)$ \\
\hline C13-N1-C9-S2 & & & $177.97(13)$ \\
\hline S1-C1-C2-C15 & & $5.9(4)$ & \\
\hline S1-C1-C6-C5 & & $177.4(3)$ & \\
\hline S1-C7-C8-S2 & & $-178.20(18)$ & \\
\hline C1-S1-C7-C8 & & $-175.9(2)$ & \\
\hline S2-C9-C10-C21 & & $-1.6(4)$ & \\
\hline C8-S2-C9-C10 & & $-171.9(2)$ & \\
\hline C9-C10-C21-S4 & & $-79.4(3)$ & \\
\hline C15-S3-C16-N1 & & $-1.5(4)$ & \\
\hline
\end{tabular}

Symmetry code: (i) $2-x, 1-y, 1-z$ for 1 and $-x, 1-y,-z$ for $2 b$.

Table 2: Selected bond lengths $(\AA)$ and angles and torsion angles $\left(^{\circ}\right)$ for 1 and $2 a$ and $2 b$.

$\AA$. The fragments $-\mathrm{CH}_{2} \mathrm{Br}$ in $\mathbf{1}$ and $-\mathrm{CH}_{2}-\mathrm{S}_{-} \mathrm{C}_{5} \mathrm{H}_{4} \mathrm{~N}$ in $\mathbf{2} \mathbf{a}$ and $\mathbf{2 b}$ are displayed in a trans arrangement (Figures 1 and 2).

In polymorph $\mathbf{2 a}$ phenyl rings are nearly coplanar while in $\mathbf{2 b}$ phenyl rings are positioned in an antiparallel manner and centroid-tocentroid distance increases when phenyl rings are nearly coplanar. In this context the polymorph 2a presents a larger centroid-to-centroid distance compared to polymorph $2 \mathbf{b}\left[\Delta d_{(\mathrm{Cg} \ldots \mathrm{Cg})}=1.258 \AA\right]$.

Crystal structures: The crystal lattice of 1 exhibits a supramolecular assembly that has a polymeric array via $\mathrm{C}-\mathrm{H} \bullet \bullet \pi, \pi \bullet \bullet \pi$ interactions of

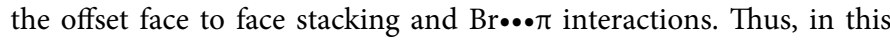
crystal lattice there is a $\mathrm{C}-\mathrm{H} \bullet \bullet \pi$ interaction between one hydrogen atom of the methylene group bonded to bromine with a phenyl ring $d_{(\mathrm{H} 8 \mathrm{a} \ldots \mathrm{Cg})}=2.947 \AA$ and $\Varangle_{(\mathrm{C} 8 \mathrm{-H} 8 \mathrm{a} \ldots . . \mathrm{Cg} 2)}=111.78^{\circ}$; also a $\pi \bullet \bullet \pi$ offset-stacked interaction is observed with $d_{(\mathrm{H} 6 \ldots . . \mathrm{Cg})}=3.465 \AA, d_{(\mathrm{Cg} \ldots \mathrm{Cg})}=4.655 \AA$ and $\Varangle$ $(\mathrm{Cg}-\mathrm{H} 6 \cdots \mathrm{Cg})=105.81^{\circ}$; finally $\mathrm{Br} \bullet \bullet \pi$ interactions are also observed with

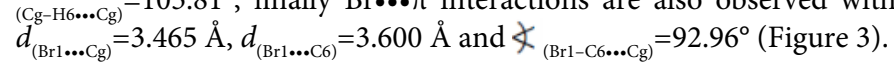

Crystal analysis of polymorphs $\mathbf{2 a}$ and $\mathbf{2 b}$ suggests the presence of different $\pi-\pi$ and $\mathrm{C}-\mathrm{H} \bullet \bullet \pi$ interactions. The crystal lattice of polymorph 2a exhibits the formation of a supramolecular, polymeric array via $\mathrm{C}-\mathrm{H} \bullet \bullet \pi$ interactions between one hydrogen atom of the methylene group linking a phenyl ring with a pyridine ring and other interactions between one hydrogen atom of the methylene group that bridges two phenyl rings $\left[\mathrm{C}-\mathrm{H} \cdots \pi \pi\right.$ interactions with $d_{(\mathrm{H} 7 \mathrm{~b} \ldots . . \mathrm{Cgl})}=2.708 \AA$ and $\Varangle_{(\mathrm{C} 7-\mathrm{H} 7 \mathrm{~b} \ldots \mathrm{Cgl})}=142.92^{\circ} ; d_{(\mathrm{H} 8 \mathrm{a} \ldots \mathrm{Cg} 2)}=2.868 \AA$ and $\Varangle_{(\mathrm{C} 8-\mathrm{H} 78 \mathrm{a} \ldots \mathrm{Cg} 2)}=143.02^{\circ} ;$ $d_{(\mathrm{H} 15 \mathrm{~b} \ldots \mathrm{Cg} 3)}=3.116 \AA$ and $\Varangle_{(\mathrm{C} 15-\mathrm{H} 15 \mathrm{~b} \ldots \mathrm{Cg} 3)}=145.68^{\circ}$; where $\mathrm{C} 1 / \mathrm{C} 2 / \mathrm{C} 3 /$ $\mathrm{C} 4 / \mathrm{C} 5 / \mathrm{C} 6=\mathrm{Cg} 1, \mathrm{C} 9 / \mathrm{C} 10 / \mathrm{C} 11 / \mathrm{C} 12 / \mathrm{C} 13 / \mathrm{C} 14=\mathrm{Cg} 2$ and $\mathrm{N} 1 / \mathrm{C} 16 / \mathrm{C} 17 /$ $\mathrm{C} 18 / \mathrm{C} 19 / \mathrm{C} 20=\mathrm{Cg} 3$, respectively] (Figure 4). Polymorph $2 \mathbf{b}$ presents a supramolecular, tetrameric assembly via $\pi \bullet \bullet \pi$ offset-stacked and $\mathrm{C}-\mathrm{H} \bullet \bullet \pi \mathrm{T}$-shaped interactions $(\pi \bullet \bullet \pi$ offset-stacked interactions between two pyridinic rings with $d_{(\mathrm{H} 10 \ldots \mathrm{Cg} 2)}=3.434 \AA d_{(\mathrm{Cg} 2 \ldots \mathrm{Cg} 2)}=4.446$ $\AA$ and $d_{\text {(intergar }}=3.380 \AA$. C-H $\bullet \bullet \pi$ T-shaped interactions are due to contacts between one hydrogen atom of one phenyl ring and another phenyl ring with $d_{(\mathrm{H} 3 \ldots \mathrm{Cgl})}=3.302 \AA, d_{(\mathrm{Cg} 1 \ldots \mathrm{Cg} 1)}=5.397 \AA$ and $\Varangle_{(\mathrm{C} 3-}$ H3... $=148.16^{\circ}$, where $\mathrm{C} 1 / \mathrm{C} 2 / \mathrm{C} 3 / \mathrm{C} 4 / \mathrm{C} 5 / \mathrm{C} 6=\mathrm{Cg} 1$ and $\mathrm{N} 1 / \mathrm{C} 9 / \mathrm{C} 10 /$ $\mathrm{C} 11 / \mathrm{C} 12 / \mathrm{C} 13=\mathrm{Cg} 2$, respectively) (Figure 5).

\section{Hirshfeld surface analysis}

The intermolecular interactions of crystal structures of $1,2 \mathrm{a}$ and $2 \mathrm{~b}$ were quantified using Hirshfeld surface analysis and fingerprint plots which are illustrated in Figure 6. Surfaces that have been mapped over a norm are shown. The relative contributions of different interactions of compounds 1, 2a and $2 \mathrm{~b}$ are presented in Figure 7.

In general, the fingerprint plots of compounds $\mathbf{1}, \mathbf{2 a}$ and $\mathbf{2 b}$ shown that dominant interactions are $\mathrm{C} \bullet \bullet \mathrm{H}(19.2-31.8 \%)$ and $\mathrm{H} \bullet \bullet \mathrm{H}$ (35.5-48.6\%), and especially in compound $\mathbf{1}$ it is observed a $\mathrm{Br} \bullet \bullet \mathrm{H}$ contribution $(28.8 \%)$, other significant $\mathrm{S} . . \bullet \mathrm{H}$ interactions have been observed varying from 10.8-17.5\%. Hirshfeld surfaces of polymorphs $\mathbf{2 a}$ and $\mathbf{2 b}$ exhibit significant differences between intermolecular interactions. Thus, in $\mathbf{2 b} \mathbf{C} \cdot \bullet \cdot \mathrm{H}$ contributions are $7.6 \%$ larger than those for $\mathbf{2 a}$; $\mathbf{H} \bullet \bullet \cdot \mathrm{H}$ contributions in $\mathbf{2 b}$ are smaller by $5.1 \%$ than in those in $\mathbf{2 a}$, S $\bullet \bullet \bullet H$ contributions are quite similar in both polymorphs $(17.0 \%$ in $\mathbf{2 a}$ and $17.5 \%$ in $\mathbf{2 b}), \mathrm{N} \bullet . . \mathrm{H}$ contributions are also similar (5.8\% in $\mathbf{2} \mathbf{a}$ and $4.0 \%$ in $\mathbf{2 b}$ ). Finally, polymorph $\mathbf{2 b}$ does not present C...C contributions while in $\mathbf{2 a}$ this contribution is $3.3 \%$. These differences in the contributions of all types of interactions found in the crystal structures of compounds $\mathbf{2 a}$ and $\mathbf{2} \mathbf{b}$ evidence that they are structurally different.

\section{Conclusion}

The crystal structure of the compound $\mathbf{1}$ and polymorphs $\mathbf{2 a}$ and 2b show different intermolecular interactions that lead to different types of supramolecular arrays. Quantification of the intermolecular interactions present in compounds $\mathbf{1}, \mathbf{2} \mathbf{a}$ and $\mathbf{2 b}$ was realized by Hirshfeld surface analysis and 2D fingerprint plots. This analysis of intermolecular contacts present in the crystal packing of $\mathbf{2 a}$ and $\mathbf{2 b}$ leads to conclude these compounds are true polymorphs. 

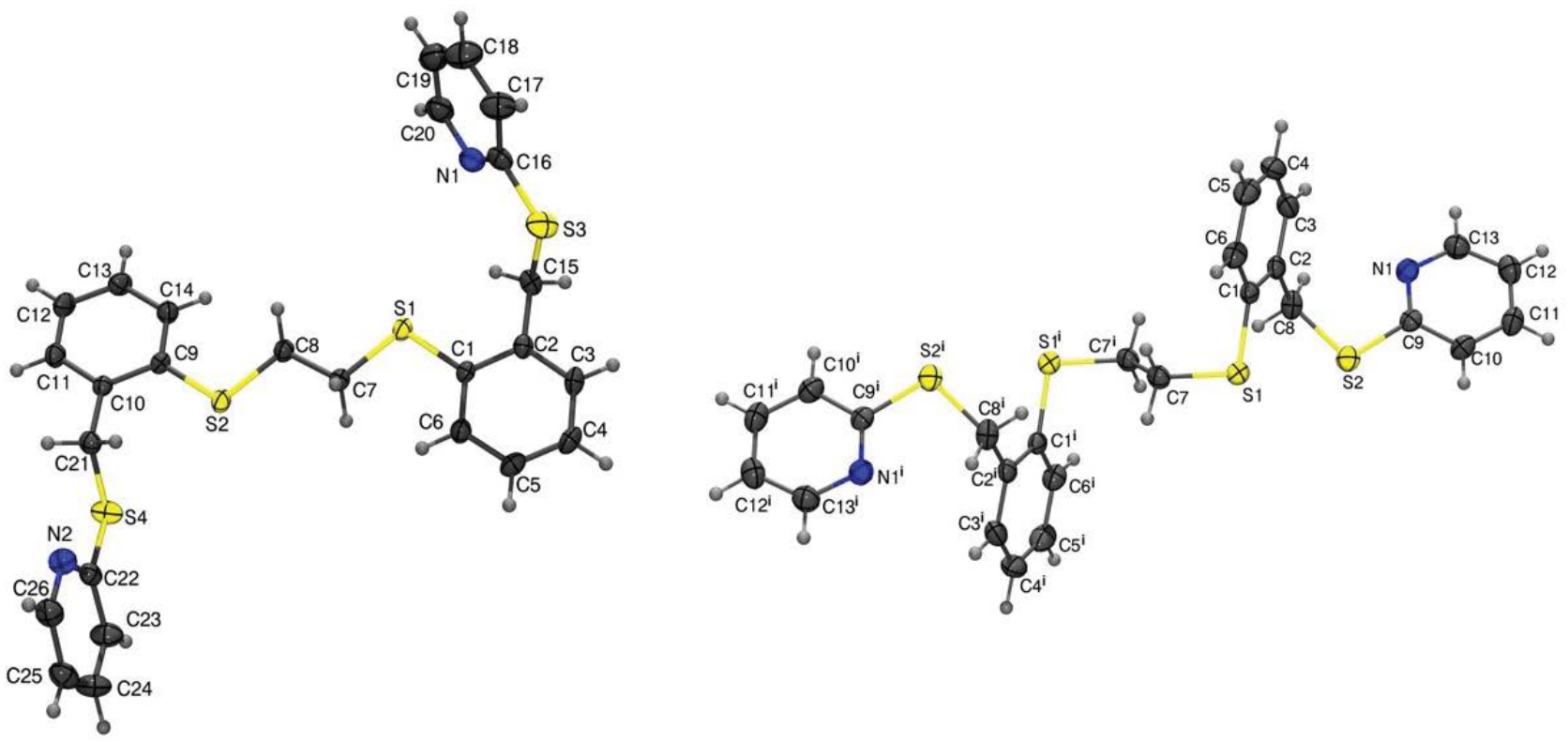

Figure 2: Molecular structure of the polymorphs $2 \mathrm{a}$ (left) and 2b (right), showing the atom labeling. Displacement ellipsoids are drawn at the $30 \%$ probability level. Symmetry code (i) $-\mathrm{x}, 1-\mathrm{y},-\mathrm{z}$.

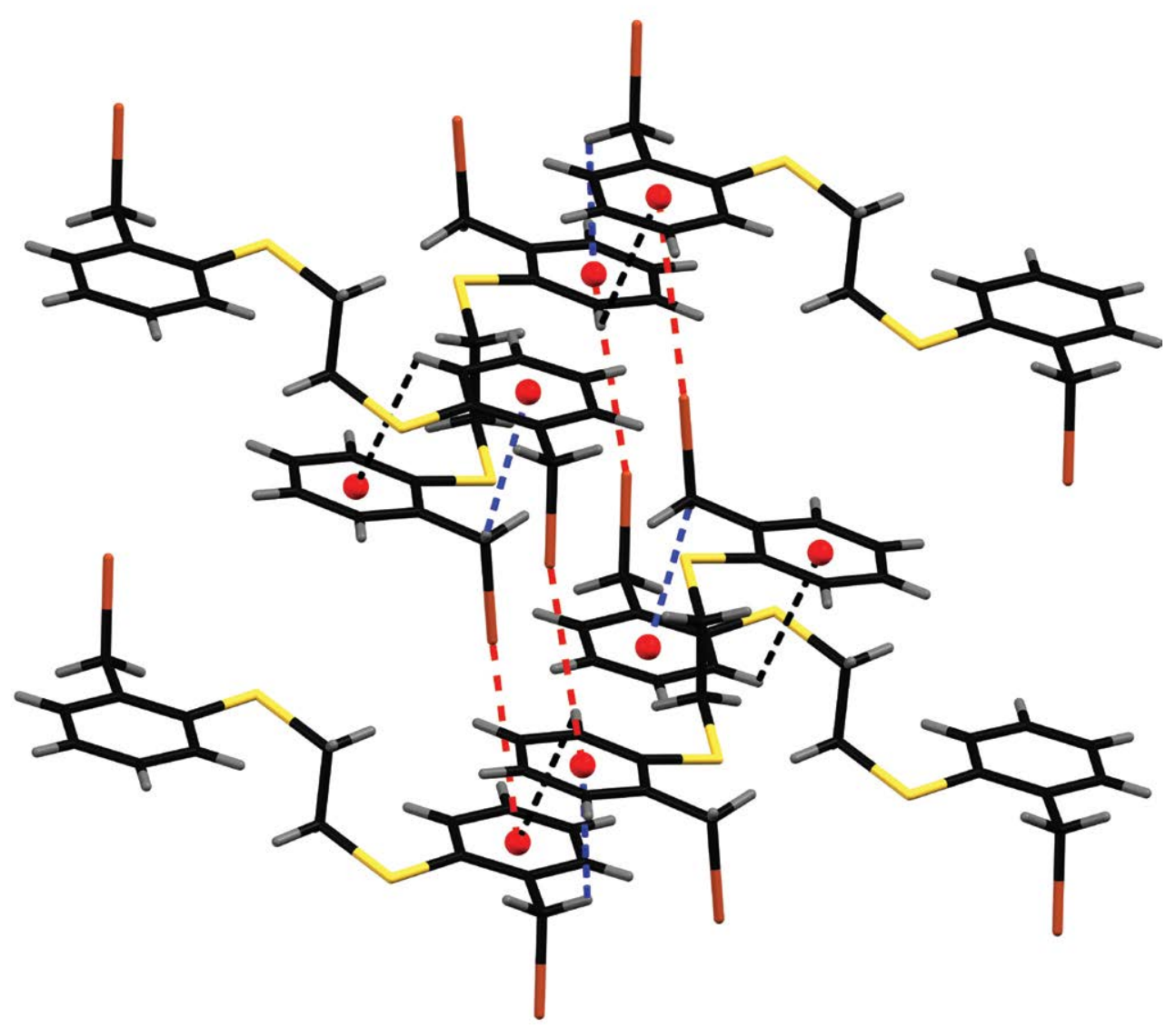

Figure 3: View of $\pi \cdots \pi$ offset-stacked, C-H $\cdots \pi$ and Hal $\cdots \pi$ interactions present in the crystal packing of 1 . (C: black; Br: brown; H: grey; S: yellow; $\pi \cdots \pi$ offset-

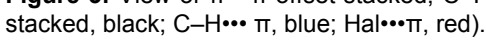


Citation: González-Montiel S, Baca-Téllez S, Martínez-Otero D, Álvarez-Hernández A, Cruz-Borbolla J, et al. (2015) Crystal Structure and Hirshfeld Surface Analysis of 1,2-Bis((2-(Bromomethyl)Phenyl)Thio)Ethane and Two Polymorphs of 1,2-Bis((2-((Pyridin-2-ylthio)Methyl)Phenyl)Thio) Ethane. Mod Chem appl 3: 154. doi:10.4172/2329-6798.1000154

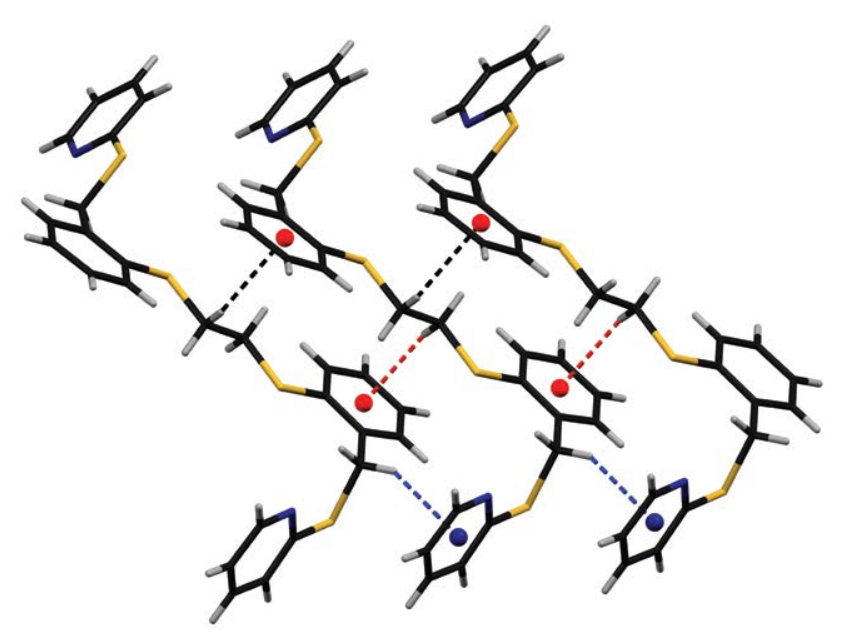

Figure 4: View of $\mathrm{C}-\mathrm{H} \cdots \pi$ interactions present in the crystal packing of 2a. (C: black; N: blue; H: grey; S: yellow; C-H... m, blue, red, black).

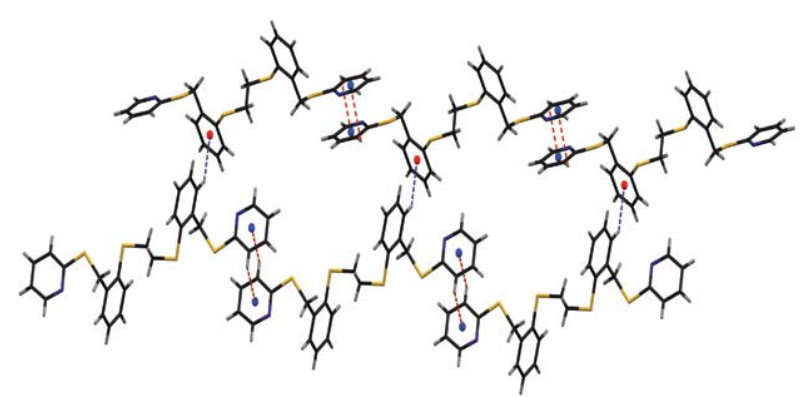

Figure 5: View of $\pi \cdots \pi$ offset-stacked, C-H $\cdots \pi$ interactions present in the crystal packing of $2 \mathrm{~b}$. (C: black; N: blue; H: grey; S: yellow; $\pi \cdots \bullet$ offset-stacked, red; $\mathrm{C}-\mathrm{H} \cdots \pi$, blue).
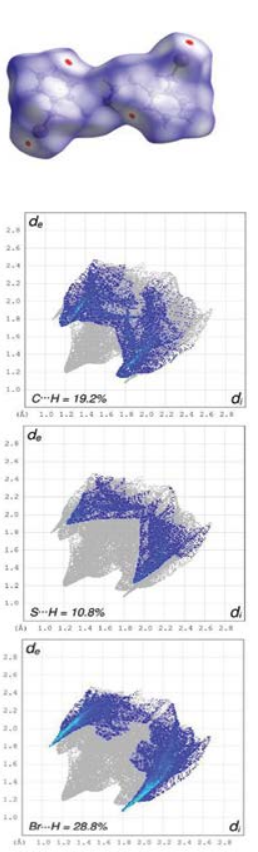
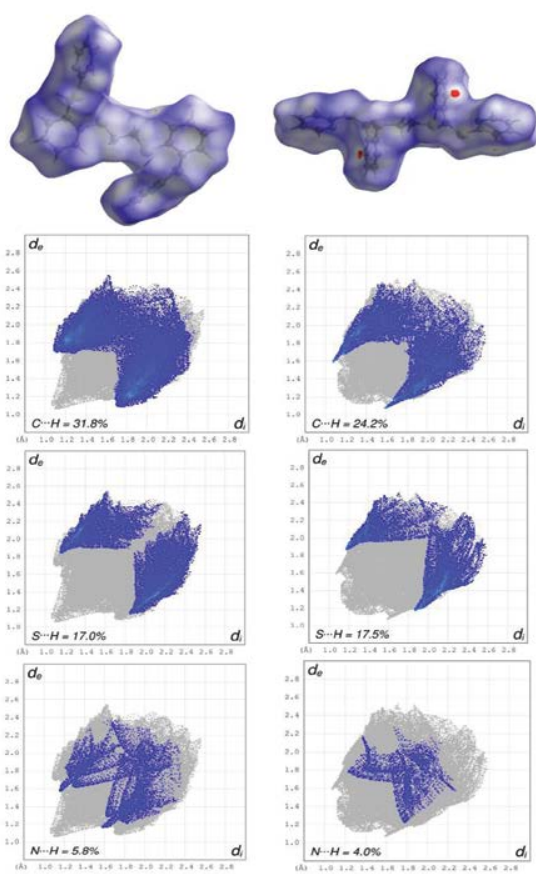

Figure 6: Hirshfeld surfaces and 2D fingerprint plots of compounds 1 (left), 2a (middle) and $2 \mathrm{~b}$ (right) showing percentage contribution of contact molecules.

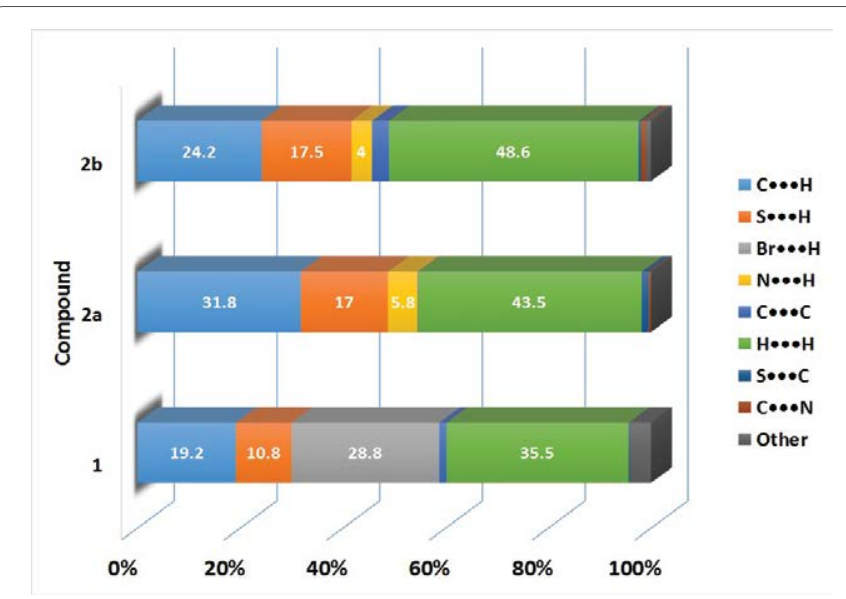

Figure 7: Percentage contribution of individual intermolecular interactions to the Hirshfeld surfaces of compounds $1,2 \mathrm{a}$ and $2 \mathrm{~b}$.

\section{Supplementary Material}

Crystallographic data for the structural analyses have been deposited with the Cambridge Crystallographic Data Center, CCDC Nos. 1037743 for $\mathbf{1}, 1037744$ for $\mathbf{2 a}$, and 1037745 for $\mathbf{2 b}$. The data can be obtained free of charge from The Director, CCDC, 12 Union Road, Cambridge CB21EZ, UK (Fax: +44-1223-336-033; E-mail: deposit@ ccdc.cam.ac.uk or http://www.ccdc.cam.ac.uk).

\section{Acknowledgements}

S.G.M. thankfully acknowledges financial support from CONACyT "México" (Grant CB-2011-01-167873) and S.B.T. is grateful for a graduate fellowship from CONACyT (352507).

\section{References}

1. Threlfall TL (1995) Analysis of organic polymorphs. A review. Analyst 120 2435-2460.

2. Berntein J, Henck JO (1998) Disappearing and reappearing polymorphs-an anathema to crystal engineering? Cryst Eng 1: 119-128.

3. Cruz-Cabeza AJ, Bernstein J (2014) Conformational polymorphism. Chem Rev 114: 2170-2191.

4. Rubcic M, Galic N, Halasz I, Jednacak T, Judaš N, et al. (2014) Multiple Solid Forms of 5-Bis(salicylidene)carbohydrazide: Polymorph-Modulated Thermal Reactivity. Cryst Growth Des 14: 2900-2912.

5. Kumar VS, Addlagatta A, Nangia A, Robinson WT, Broder CK, et al (2002) 4,4-Diphenyl-2,5-cyclohexadienone: four polymorphs and nineteen crystallographically independent molecular conformations. Angew Chem Int Ed Engl 41: 3848-3851.

6. Yu V, Shavit E, Weissbuch I, Leiserowitz L, Lahav M (2005) Control of Crystal Polymorphism by Tuning the Structure of Auxiliary Molecules as Nucleation Inhibitors. The $\beta$-Polymorph of Glycine Grown in Aqueous Solutions. Cryst Growth Des 5: 2190-2196.

7. Roy S, Nangia A (2007) Kinetic and Thermodynamic Conformational Polymorphs of Bis(p-tolyl) Ketone p-Tosylhydrazone: The Curtin-Hammett Principle in Crystallization. Cryst Growth Des 7: 2047-2058.

8. Zhang $W$, Tang $X$, Ma H, Wen-Hua S, Janiak C (2008) \{2-[1-(2,6-Diisopropylphenylimino)ethyl]pyridyl\}palladium Dibromide Polymorphs Originating from Different $\mathrm{Br} \cdots \pi$ and $\mathrm{C}-\mathrm{H} \cdots \mathrm{Br}$ Contacts. Eur $\mathrm{J}$ Inorg Chem 2008: 2830-2836.

9. Ueda K, Oguni M, Asaji T (2014) Halogen Bond as Controlling the Crystal Structure of 4-Amino-3,5-Dihalogenobenzoic Acid and Its Effect on the Positional Ordering/Disordering of Acid Protons. Cryst Growth Des 14: 61896196.

10. Priimagi A, Cavallo G, Metrangolo P, Resnati G (2013) The halogen bond in 
Citation: González-Montiel S, Baca-Téllez S, Martínez-Otero D, Álvarez-Hernández A, Cruz-Borbolla J, et al. (2015) Crystal Structure and Hirshfeld Surface Analysis of 1,2-Bis((2-(Bromomethyl)Phenyl)Thio)Ethane and Two Polymorphs of 1,2-Bis((2-((Pyridin-2-ylthio)Methyl)Phenyl)Thio) Ethane. Mod Chem appl 3: 154. doi:10.4172/2329-6798.1000154

Page 7 of 7

the design of functional supramolecular materials: recent advances. Acc Chem Res 46: 2686-2695.

11. Mukherjee A, Tothadi S, Desiraju GR (2014) Halogen bonds in crystal engineering: like hydrogen bonds yet different. Acc Chem Res 47: 2514-2524.

12. Jentzsch AV, Hennig A, Mareda J, Matile S (2013) Synthetic ion transporters that work with anion-m interactions, halogen bonds, and anion-macrodipole interactions. Acc Chem Res 46: 2791-2800.

13. Aitipamula S, Chow PS, Tan RBH (2014) Crystal Engineering of Tegafur Cocrystals: Structural Analysis and Physicochemical Properties. Cryst Growth Des 14: 6557-6569.

14. Landenberger KB, Matzger AJ (2012) Cocrystals of 1,3,5,7-Tetranitro-,3,5,7tetrazacyclooctane (HMX). Cryst Growth Des 12: 3603-3609.

15. Sarcevia I, Orola L, Veidis MV, Podjava A, Belyahov S (2013) Crystal Structures and Density Functional Theory Calculations of o- and p-Nitroaniline Derivatives: Combined Effect of Hydrogen Bonding and Aromatic Interactions on Dimerization Energy. Cryst Growth Des 12: 3603-3609.

16. McKinnon JJ, Spackman MA, Mitchell AS (2004) Novel tools for visualizing and exploring intermolecular interactions in molecular crystals. Acta Crystallogr B 60: $627-668$

17. McKinnon JJ, Mitchell AS, Spackmann MA (1998) Hirshfeld Surfaces: A New Tool for Visualising and Exploring Molecular Crystals. Chem Eur J 4: 21362141

18. Spackmann MA, McKinnon JJ (2002) Fingerprinting intermolecular interactions in molecular crystals. Cryst Eng Comm 4: 378-392.

19. Bakavoli M, Rahimizadeh M, Feizyzadeh B, Kaju AG, Takjoo R (2010) 3,6-Di(pchlorophenyl)-2,7-dihydro-,4,5-thiadiazepine: Crystal Structure and Decoding Intermolecular Interactions with Hirshfeld Surface Analysis. J Chem Crystallogr 40: 746-752.

20. Seth SK, Saha I, Estarellas C, Frontera A, Kar T, et al. (2011) Supramolecular Self-Assembly of M-IDA Complexes Involving Lone-Pair $\cdots \pi$ Interactions: Crystal Structures, Hirshfeld Surface Analysis, and DFT Calculations [ $\mathrm{H}_{2} \mathrm{IDA}=$ iminodiacetic acid, $\mathrm{M}=\mathrm{Cu}(\mathrm{II}), \mathrm{Ni}(\mathrm{II})]$. Cryst Growth Des 11: 3259-3265.
21. Moggach SA, Allan DR, Parsons S, Sawyer L (2006) Effect of pressure on the crystal structure of alpha-glycylglycine to $4.7 \mathrm{GPa}$; application of Hirshfeld surfaces to analyse contacts on increasing pressure. Acta Crystallogr B 62 : 310-320.

22. Tarahhomi A, Pourayoubi M, Golen JA, Zargaran P, Elahi B, et al. (2013) Hirshfeld surface analysis of new phosphoramidates. Acta Crystallogr B Struct Sci Cryst Eng Mater 69: 260-270.

23. Wong HL, Allan DR, Champness NR, McMaster J, Schröder M, et al. (2013) Bowing to the pressure of $\pi \cdots \pi$ interactions: bending of phenyl rings in a palladium(II) thioether crown complex. Angew Chem Int Ed Engl 52: 50935095

24. Titi HM, Patra R, Goldberg I (2013) Exploring supramolecular self-assembly of tetraarylporphyrins by halogen bonding: crystal engineering with diversely functionalized six-coordinate $\operatorname{tin}(\mathrm{L}) 2$-porphyrin tectons. Chemistry 19: 14941 14949.

25. Tawfiq KM, Miller GJ, Al-Jeboori MJ, Fennell PS, Coles SJ, et al. (2014) Comparison of the structural motifs and packing arrangements of six nove derivatives and one polymorph of 2-(1-phenyl-1H-1,2,3-triazol-4-yl)pyridine. Acta Crystallogr B Struct Sci Cryst Eng Mater 70: 379-389.

26. González-Montiel S, Baca-Téllez S, Martínez-Otero D (2015) Construction of 18-membered monometallic macrocycles by a trans-spanning ligand. Polyhedron 92: 22-29.

27. Taylor MK, Trotter KD, Reglinski J, Berlouis LEA, Kennedy AR, et al. (2008) Copper $\mathrm{N}_{2} \mathrm{~S}_{2}$ Schiff base macrocycles: The effect of structure on redox potential. Inorg Chim Acta 361: 2851-2862.

28. Oxford Diffraction (2009) CRYSALIS software system, version 1.171.33.31 Oxford Diffraction Ltd., Abingdon, UK.

29. Dolomanov OV, Bourhis LJ, Gildea RJ, Howard JAK, Puschmann H (2009) OLEX2: a complete structure solution, refinement and analysis program. J App Cryst 42: 339-341.

30. Sheldrick GM (2008) A short history of SHELX. Acta Crystallogr A 64: 112-122.

31. Wolff SK, Greenwood DJ, McKinnon JJ, Jayatilaka D, Spackman MA (2007) Crystal Explorer 2.0. University of Western Australia, Perth. 